method $^{6}$ was used with an incubation period of $18 \mathrm{hr}$. A 43-64 per cent decrease of $\beta$-glucuronidase activity was found in the post-heparin sera. Cajani ${ }^{7}$ noted that $\beta$-glucuronidase showed a 2,000-times greater affirity for heparin than for phenolphthalein $\beta$-glucuronide. Klesper and Dohrmann ${ }^{8}$ demonstrated an anti-coagulant effect of $\beta$-glucuronidase in vitro. Kayahan $^{8}$ found a similar effect in vivo and also showed a decrease of lipæmia after administration of B-glucuronidase.

From these observations the following hypothesis, among others, appears reasonable: $\beta$-glucuronidase and heparin form a complex having not only an anti-coagulant power but also a lipoprotein-lipase activating or enhancing effect.

Minály Bartalos FERENC Györkey

Departments of Pathology,

The Johns Hopkins University

and Baltimore City Hospitals, Baltimore, Maryland.

Zsolt KoppánYI

Department of Pediatrics,

Baltimore City Hospitals,

Baltimore, Maryland.

${ }^{1}$ Hahn, P. F., Science, 88,19 (1943).

'Levy, S. W., and Swank, R. L., J. Physiol., 123, 301 (1954).

s Skorepa, J., and Todorovicova, H., Experientia, 12, 278 (1958).

4 Pav, J., and Wenkeova, J., Clin. Chem. Acta, 5, 90 (1960).

s Dohrmann, R., Deutsch. Arch. klin. Med., 206, 322 (1960).

- Fishman, W. H., Springer, B., and Brunetti, R., J. Biol. Chem., 173,449 (1948).

${ }^{7}$ Cajani, F., Atti Soc. Lombarda sci. med. biol., 12, 286 (1957); Chem. Abst., $52,4716 i$ (1958).

'Klesper, R., and Dohrmann, R., Acta Haemat., 25, 228 (1961).

- Kayahan, S., Lancet, il, 667 (1960).

\section{Excretion of 5-Hydroxy Indolyl-Acetic Acid after Surgery}

Although the healing of a wound is an essentially local event, it must inevitably also involve wider metabolic processes in the whole organism. One metabolic excretory product of dietary tryptophan is 5-hydroxy indolyl-acetic acid (5-HIAA) derived via the intermediate metabolites 5-hydroxytryptophan (5-HTP) and 5-hydroxytryptamine (5-HT). Special interest has been devoted to this pathway because of its significance in carcinoid tumours. Certain of the metabolic and clinical changes produced by 5-HT may, however, also be important in tissue regeneration and the healing of wounds. As a method of investigat. ing this, it was decided to study the excretion of 5.HIAA following wounding.

5-Hydroxytryptamine metabolism is notoriously difficult to study as it varies from animal to animal, and a number of confusions and contradictions observed in the past stemmed from this difficulty. The investigation reported here was carried out on human subjects. A 'standard experimental' wound was made by using patients with the same clinical condition and operation.

One of the most uniform operations is the repair of a moderate-sized inguinal hernia in the adult male. We therefore used 14 patients on whom this operation was to be carried out, by the same surgeon (G. T. W.). The patients were of a similar age-group (25-35 years) and all were admitted to the same ward. By this means it was hoped to standardize the form of mental and physical stress to which the patients were subjected. The diet was the regular hospital one, modified by exclusion of any items known to be high in tryptophan metabolites (for example, bananas, spinach, pineapple juice). The men were admitted to hospital 2 days before operation and no specimens were collected in the first $12 \mathrm{hr}$. The urine was then collected over each $24 \mathrm{hr}$. That passed during the day of operation was discarded. All specimens were collected in bottles containing $10 \mathrm{ml}$. glacial acetic acid and analyses made as soon as possible. Experiments showed, however, that if longer storage was unavoidable no significant change in 5-hydroxy indolyl-acetic acid content occurred for at least one week if the acidified sample was deep-frozen to $-20^{\circ} \mathrm{C}$. Assays were made using a modification of the method of Udenfriend, Titus and Weissbach ${ }^{1}$. The results were expressed in $\mathrm{mgm}$. of 5 -hydroxy indolyl-acetic acid excreted every $24 \mathrm{hr}$. With this method the normal range for laboratory staff fell between the values $2-9 \mathrm{mgm} . / 24 \mathrm{hr}$.

Table 1. URINARY 24-Hr. 5-HIAA OUTPUT EXPRESSED IN MGM./24 HR.

\begin{tabular}{|c|c|c|c|}
\hline First & $\begin{array}{l}\text { Days afte } \\
\text { Second }\end{array}$ & $\begin{array}{l}\text { peration } \\
\text { Third }\end{array}$ & Fourth \\
\hline $10 \cdot 5$ & - & - & - \\
\hline & $=$ & - & \\
\hline 6.4 & $=$ & - & - \\
\hline $\begin{array}{c}6.1 \\
10 \cdot 6\end{array}$ & $13 \cdot 2$ & $7 \cdot 4$ & 6.8 \\
\hline $9 \cdot 4$ & $\begin{array}{l}5 \cdot 9 \\
8.7\end{array}$ & $7 \cdot 0$ & \\
\hline & 4.5 & $10 \cdot 2$ & 一 \\
\hline $15 \cdot 8$ & $8 \cdot 1$ & 6.7 & \\
\hline $\begin{array}{l}10.6 \\
24.2\end{array}$ & $\begin{array}{r}2.99 \\
11 \cdot 6\end{array}$ & $\begin{array}{r}40 \cdot 8 \\
10 \cdot 6\end{array}$ & 5.8 \\
\hline $10 \cdot 1$ & $5 \cdot 1$ & $\begin{array}{r}10.2 \\
3.5\end{array}$ & $\begin{array}{r}12 \cdot 1 \\
6.1\end{array}$ \\
\hline
\end{tabular}

Table 1 shows the pre- and post-operative levels of urinary 5-HIAA in the 14 patients examined. These figures indicate that with but one exception (case 5) the urinary 5-HIAA output was significantly increased on the first day following surgery. That such changes were not a function of a generalized increase in nonprotein nitrogen metabolism was excluded in parallel urea nitrogen and creatinine measurements on the same samples. These showed no such changes after surgery. Parallel daily platelet counts were made in 6 cases; no significant correlation was evident. This shows that the alterations in 5-HIAA output are not related to an enhanced 5-HT metabolism consequent on an increase in post-operative circulating platelets. This does not of course exclude the possibility that an abnormal release of 5-HT from platelets may occur without change in the number circulating.

The urine samples from 6 cases were examined chromatographically. The results for 5-HIAA when assessed by a semiquantitative method were in general agreement with the colorimetric assays. It was also noted that in some instances certain other indole metabolites, notably indolyl acetic acid (IAA) and potassium indoxyl sulphate (indican), were also increased post-operatively and to approximately the same degree as 5-HIAA.

We thank Prof. F. A. R. Stammers, and Dr. G. B. Leyton of the Hollymoor Hospital for assistance with the chromatographic studies. This work was supported by the Medical Research Council and U.S. National Heart Institute (Grant No. H5772).

Nevinle Crawford

George T. WATtS

Division of Wound Healing Research,

Department of Surgery,

University of Birmingham.

${ }^{1}$ Udenfriend, S., Titus, E., and Weissbach, H., J. Biol. Chem., 216, 